\title{
Genetic and phenotypic parameter on fertility traits of Red Chittagong Cattle in Bangladesh
}

\author{
M. A. Habib, A. K. F. H. Bhuiyan* and M. R. Amin' \\ Department of Animal Breeding and Genetics, Faculty of Animal Husbandry, Bangladesh \\ Agricultural University, Mymensingh-2202, Bangladesh
}

\begin{abstract}
The fertility of Red Chittagong Cattle (RCC) of Bangladesh was studied using data from 122 animals from four herds. The least squares means of female fertility traits were $1.4 \pm$ $0.1,72.6 \pm 3.6 \%$ and $85.0 \pm 2.0 \%$, respectively, for number of services per pregnancy, first service pregnancy rate and overall pregnancy rate. The least squares mean of non-return rate to first service of bull was $58.7 \pm 5.1 \%$. The factor having a significant effect on female fertility was herd, while parity had no effect. Herd and parity of dam, season of service and sire had no effect on non-return rate to first service of bull. The heritability of fertility traits were very low: values were $0.07 \pm 0.04,0.03 \pm 0.04,0.05 \pm 0.04$ and 0 , respectively, for number of services per pregnancy, first service pregnancy rate, overall pregnancy rate and non-return rate to first service of bull. The corresponding repeatability values were $0.18 \pm$ $0.08,0.08 \pm 0.07,0.13 \pm 0.08$ and $-0.07 \pm 0.02$, respectively. This study reveals the fertility to be good. However, better reproductive management may enhance the overall herd fertility of RCC. (Bangl. vet. 2012. Vol. 29, No. 2, 78 -89)
\end{abstract}

\section{Introduction}

Poor fertility is of economic importance for dairy enterprises, because it results in higher levels of involuntary replacement and reduced annual milk production (Goshu et al., 2007). Calving interval of 12 to 13.5 months, 1.3 to 1.5 services per conception and 85 days open are considered as standard values (McDowell 1985; Radostits 2001). Fertility of dairy cows is influenced by genetics, season, age, production system, nutrition, management, environment and disease. Low fertility of cattle in the tropics is probably related to inadequate nutrition, disease and parasites (Mukasa-Mugerwa, 1989). RCC of Bangladesh is a promising variety. The fertility traits of RCC are comparable with Bos taurus and some other indigenous cattle available in the Indian subcontinent and some countries of Africa. Comprehensive reports are not available in this variety of cattle. This study was conducted to investigate the genetic and nongenetic control of fertility of RCC in Bangladesh.

\section{Materials and Methods}

\section{Study site}

The study was conducted from four different RCC herds located at Anwara (22010' to $22^{\circ} 14^{\prime} \mathrm{N}$ and $91052^{\prime}$ to $\left.91{ }^{\circ} 56^{\prime} \mathrm{E}\right)$ and Chandanaish $\left(22^{\circ} 12^{\prime}\right.$ to $22^{\circ} 14^{\prime} \mathrm{N}$ and $92^{\circ} 0^{\prime}$ to

\footnotetext{
${ }^{1}$ Faculty of Agro based Industry, University Malaysia Kelantan, Malaysia

* Corresponding author:- E-mail: bhuiyanbau@gmail.com
} 
92006' E) Upazilas (Sub-district) in Chittagong district and Bangladesh Agricultural

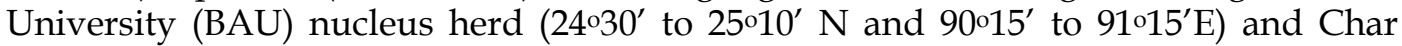
Jailkhan community herd $\left(24^{\circ} 77^{\prime}\right.$ to $24^{\circ} 78^{\prime} \mathrm{N}$ and $90^{\circ} 39^{\prime}$ to $\left.90^{\circ} 41^{\prime} \mathrm{E}\right)$ in Mymensingh district. There is a tropical monsoon-type climate with warm temperatures throughout the year, with a hot and rainy summer and a dry winter with little variation from month to month. January tends to be the coolest month with temperatures averaging near $26^{\circ} \mathrm{C}\left(78^{\circ} \mathrm{F}\right)$ and April/May the warmest with temperatures from 33 to $36^{\circ} \mathrm{C}\left(91\right.$ to $\left.96^{\circ} \mathrm{F}\right)$. Most places receive more than $1,525 \mathrm{~mm}$ of rain a year, and areas near the hills receive 5,080 $\mathrm{mm}$. Most rains occur during the monsoon (June - September) and little in winter (November - February) (Source: http:/ / www.discoverybangladesh.com/meetbangladesh/climate.html).

\section{Management of animals}

The feeding and management was semi-intensive. Animals grazed 6-8 h/ day. Roadside grasses were the basal diet, with rice straw, specially during cropping seasons. Most farmers provided rice bran and common salt, and gave drinking water daily. Housing was traditional in a house made of bamboo with thatched roofs. The feeding and management of RCC at BAU nucleus herd was solely intensive. Animals were housed in a paddock with an open house. Animals of the nucleus herd were stall fed throughout the year. The animals were provided concentrate, green grass and straw with urea and, or, molasses. Urea-molasses-straw or sometimes only molasses-straw were provided twice a day ad libitum throughout the year. Inadequate green forages (German grass, Sorghum grass, Maize fodder) and roadside grasses were provided. Concentrate mixture was supplied each morning at $600 \mathrm{~g} /$ lactating cow, 500 $\mathrm{g} /$ pregnant cow, $250 \mathrm{~g} /$ dry cow and heifer and $1500 \mathrm{~g} / \mathrm{stud}$ bull. In addition, germinated grams at $100 \mathrm{~g} /$ day were provided to breeding bulls. The pregnant cows were transferred to a separate house a few days prior to calving and returned a few days after calving. The calves were allowed to suck their dam for a few hours after milking and again a few hours before evening, up to 3-4 months. Afterwards, calves were allowed to suck once a day after milking until weaning. Semen was collected from RCC bulls once a week with artificial vagina and diluted with extender to preserve for three days at normal refrigeration temperature. In the herds of Chittagong, farmers seldom vaccinate and deworm their animals. In the BAU nucleus and community herd in Mymensingh, animals were dewormed and vaccinated against foot and moth disease and anthrax at regular intervals.

\section{Animals and data preparation}

The data consisted of records of 249 services to 110 dams sired by 12 bulls with known identity and 14 bulls with unknown identity (due to natural services) 2005 to 2011. For the analysis of male fertility (non-return rate to first services), the records of 307 services to 110 dams in the two herds (nucleus and community) sired by 8 bulls at BAU AI centre were examined (Table 1).

All unauthentic or doubtful data, extreme values from animals assumed to be reproductive problems, missing identification or other anomalies were removed. The number of removed data varied from 0 to $0.4 \%$ (Table 2). 
Table 1. Total data set

\begin{tabular}{l|cccccc}
\hline \multirow{2}{*}{ Traits } & \multicolumn{5}{c}{ Number of observations (N) } \\
\cline { 2 - 6 } & Herd-1 & Herd-2 & Herd-3 & Herd-4 & Total \\
\hline Number of services per pregnancy (NSP) & 31 & 45 & 98 & 75 & 249 \\
First service pregnancy rate (FSPR) & 31 & 45 & 98 & 75 & 249 \\
Overall pregnancy rate (PR) & 31 & 45 & 98 & 75 & 249 \\
Non-return rate to first service (NRRFS) & - & - & 307 & - & 307 \\
\hline
\end{tabular}

Table 2. Final data set after applying checking and editing criteria for analyses

\begin{tabular}{l|c|c|c|c|c}
\hline \multicolumn{1}{c|}{ Traits $^{1}$} & Total records & Accepted range & \multicolumn{2}{|c|}{ Records removed } & \multirow{2}{*}{ Records used } \\
\cline { 3 - 5 } & & & No. & $\%$ & \\
\hline NSP & 249 & $1-5$ nos. & 1 & 0.4 & 248 \\
FSPR & 249 & $0-100 \%$ & 0 & 0 & 249 \\
PR & 249 & $20-100 \%$ & 1 & 0.4 & 248 \\
NRRFS & 307 & $0-100 \%$ & 0 & 0 & 307 \\
\hline
\end{tabular}

1Traits described in Table 1

\section{Traits analyzed}

Traits considered in the analyses included: number of services per pregnancy (NSP) calculated from the number of cows becoming pregnant and the total number of services given; first service pregnancy rate (FSPR) the percentage of heifers/cows that became pregnant after the first service; overall pregnancy rate (PR) calculated from the proportion of cows becoming pregnant and number of all services given; and nonreturn rate to first service (NRRFS) of bull calculated from the proportion of cows not seen to return to oestrus after first service and number of services.

Data analysis and statistical model

Animals were arranged in contemporary groups according to parity, herd and season of service. The general linear model (GLM) procedure of SPSS 11.5 was used to test the main fixed effects as well as interactions that influenced the fertility traits. The following generalized linear model was used for least squares analysis:

$\mathrm{Y}_{\mathrm{ij}}=\mu+\operatorname{par}_{\mathrm{i}}+\operatorname{hrd}_{\mathrm{j}}+\mathrm{e}_{\mathrm{ijk}}$ (for female fertility traits)

$\mathrm{Y}_{\mathrm{ijkl}}=\mu+\operatorname{par}_{\mathrm{i}}+\mathrm{hrd}_{\mathrm{j}}+\mathrm{sea}_{\mathrm{k}}+$ bull $_{1}+\mathrm{e}_{\mathrm{ijklm}}$ (for male fertility trait)

Where, $\mathrm{Y}_{\mathrm{ij}}=$ Dependent variables (NSP, FSPR and PR)

$\mathrm{Y}_{\mathrm{ijkl}}=$ Dependent variable (NRRFS)

$\mu=$ Overall population mean for the trait;

pari is the fixed effect of parity $(0-7+)$,

$\mathrm{hrd}_{\mathrm{j}}$ is the fixed effect of herd ( 4 herds, but 2 herds for NRRFS), 
sea $_{\mathrm{k}}$ is the fixed effect of season of service (3 seasons),

bull $_{\mathrm{m}}$ is the fixed effect of bull ( 8 bulls), and

$\mathrm{e}_{\mathrm{ijk}}$ and $\mathrm{e}_{\mathrm{ijk} k \mathrm{~m}}$ are the random residual errors

Heritability was estimated using REML procedure by VCE 4.2.5 software (Groeneveld, 1998) with single trait animal model. Random effect considered in the model was animal's additive genetic effect. In the animal model parity, herd, season of service and individual bull were included as fixed effects. Each year was divided into 3 seasons: March - June (summer), July - October (rainy) and November February (winter). All relationships among individuals were considered in the animal model. The general form of animal model was as follows:

$\mathrm{Y}=\mathrm{Xb}+\mathrm{Za}+\mathrm{Wc}_{\mathrm{c}}+\mathrm{e}$

Where, $\quad \mathrm{Y}=$ Vector of observations

$\mathrm{X}, \mathrm{Z}$, and $\mathrm{W}=$ Known incidence matrices associated with levels of $\mathrm{b}$, $\mathrm{a}$ and $\mathrm{c}$ with $\mathrm{Y}$.

$b=$ Unknown vector of fixed effects (parity, herd, season etc.)

$\mathrm{a}=$ Unknown vector of breeding value

$c=$ Unknown vector of permanent environmental effects

$\mathrm{e}=$ Vector of residual effect

The animals selected for repeatability estimation of fertility traits were those with more than one service. Repeatability was estimated by intra-class correlations from analysis of variance with the following formula (Lush, 1945):

Repeatability $(\mathrm{r})=\sigma^{2}{ }_{\mathrm{B}} /\left(\sigma^{2}{ }_{\mathrm{B}}+\sigma^{2}{ }_{\mathrm{w}}\right)$, where $\sigma^{2} \mathrm{~B}$ is the variance between animals and $\sigma^{2}{ }_{\mathrm{w}}$ is the variance within animals. The standard error of repeatability was estimated as described by Swiger et al. (1964).

\section{Results and Discussion}

Estimation of phenotypic parameters

Table 3 presents the overall means $( \pm$ SE) and range of fertility traits of RCC for four different herds.

Table 3. Mean, standard error (SE), minimum (Min.), maximum (Max.) for fertility traits of RCC

\begin{tabular}{l|c|c|c|c|c}
\hline \multicolumn{1}{c|}{ Trait $^{1}$} & Number of & Mean & SE & \multicolumn{2}{c}{ Range } \\
\cline { 5 - 6 } & records & & & Min. & Max. \\
\hline NSP & 248 & 1.36 & 0.06 & 1 & 5 \\
FSPR & 249 & 72.56 & 3.64 & 0 & 100 \\
PR & 248 & 85.03 & 2.04 & 0 & 100 \\
NRRFS & 316 & 58.73 & 5.07 & 0 & 100 \\
\hline
\end{tabular}

1Traits described in Table 1 


\section{Number of services per pregnancy (NSP)}

The mean number of services per pregnancy was $1.4 \pm 0.1$. Habib (2011) found $1.4 \pm$ 0.1 for the same herds. The result is similar to the reports $(1.2$ to $1.4 \pm 0.1)$ reviewed by Azizunnesa et al. (2010); Das et al. (2010); Habib et al. (2003) for the same genotype in different herds. Higher range (1.5 $4 \pm 0.1$ to $1.6 \pm 0.6)$ was reported by Hossain et al. (2006); Bag et al. (2010) in the same genotype in different herds. The variations may be due to differences in management, skill of inseminator and subfertile bulls. Shiferaw et al. (2003) found that cows with reproductive disorders required more services per pregnancy. Tadesse and Zelalem (2003) noted a decrease in the services required per pregnancy for cows supplemented with protein.

\section{First service pregnancy rate (FSPR)}

The overall first service pregnancy rate in four different herds is $72.6 \pm 3.6 \%$, higher than $65.5 \pm 6.7 \%$ as reported earlier (Habib, 2011), and higher than the $63.1 \%$ in Holstein heifers in Cuba (Buxadera and Dempfle, 1997), 60\% in Angus heifers (Bormann et al., 2006), 33.9\% for crossbred cows in Kashmir Valley (Bhattacharyya et al., 2010), 45.9\% for crossbred cows in Ethiopia (Mureda and Zeleke, 2007). The variation might be due to type of cattle or non-genetic factors.

\section{Overall pregnancy rate (PR)}

The average pregnancy rate in RCC in four herds was $85.0 \pm 2.0 \%$, near to the $81.5 \pm$ 3.7 (Habib, 2011). Das et al. (2010) found $65.8 \pm 4.5 \%$ pregnancy rate in the same herd, which is much lower than in the present study: this could be due to small number of data. Pregnancy rate depends on genetic and non-genetic factors, including body condition score, genital health, correct oestrus detection, semen quality, time of insemination, efficiency of inseminator and fertility of bulls. Rodriguez and Hernandez (1992) found significant variations in pregnancy rate at different times of insemination after the first sign of oestrus. Higher ambient temperature and relative humidity (Zakari et al., 1981) and poor management reduce fertility in cattle.

\section{Non-return rate to first service (NRRFS)}

The mean non-return rate to first service of RCC bulls was $58.7 \pm 5.1 \%$, which is closely in agreement $(63.1 \pm 5.7 \%)$ with Habib (2011). The earlier work in the same herd reported 60-day non-return rate of RCC bulls as $63.9 \pm 4.2 \%$ (Das et al., 2010), which is in line with this study. Miglior et al. (1997) reported $65.4 \%$ for HolsteinFriesian in Italy. Schaeffer (1993) and Fryer et al. (1958) reported values from 52.1 to $75.7 \%$ and 44 to $71 \%$, respectively, in different ages of exotic dairy breeds. Almquist (1995) reported the average non-return rate for high fertility bulls ranged from 65 to $74 \%$ and average non-return rate for low fertility bulls ranged from 52 to $65 \%$. The result of this study falls within the range of the published literatures. The variations between authors might be due to sample size and herd management. 


\section{Effect of non-genetic factors}

Table 4 represents the least square means of the female fertility traits for the effects of herd and parity. Table 5 shows the results of the analysis of variance for traits analyzed.

Table 4. Least square means (LSM) and standard error of means (SEM) of fertility traits $^{1}$

\begin{tabular}{l|cccc}
\hline \multirow{2}{*}{ Factors $^{2}$} & NSP (no) & FSPR (\%) & PR (\%) \\
\cline { 2 - 4 } & & \multicolumn{3}{c}{ LSM \pm SEM } \\
\hline Herd & ${ }^{* * *}$ & $* * *$ & $* * *$ \\
Site-1 & $1.1^{\mathrm{a}} \pm 0.2(31)$ & $86.7^{\mathrm{a}} \pm 8.6(31)$ & $93.4^{\mathrm{a}} \pm 4.8(31)$ \\
Site-2 & $1.1^{\mathrm{a}} \pm 0.1(45)$ & $90.4^{\mathrm{a}} \pm 7.2(45)$ & $95.3^{\mathrm{a}} \pm 4.0(45)$ \\
Site-3 & $1.6^{\mathrm{b}} \pm 0.1(98)$ & $64.3^{\mathrm{b}} \pm 5.2(98)$ & $79.2^{\mathrm{b}} \pm 2.9(98)$ \\
Site-4 & $1.7^{\mathrm{b}} \pm 0.1(74)$ & $48.9^{\mathrm{b}} \pm 5.6(74)$ & $72.2^{\mathrm{b}} \pm 3.1(74)$ \\
Parity & NS & NS & NS \\
0 & $1.4 \pm 0.1(54)$ & $66.8 \pm 6.4(54)$ & $81.8 \pm 3.6(54)$ \\
1 & $1.2 \pm 0.1(36)$ & $81.3 \pm 7.9(36)$ & $90.4 \pm 4.4(36)$ \\
2 & $1.4 \pm 0.1(35)$ & $66.4 \pm 8.0(35)$ & $82.8 \pm 4.4(35)$ \\
3 & $1.4 \pm 0.1(45)$ & $70.7 \pm 6.8(45)$ & $83.6 \pm 3.8(45)$ \\
4 & $1.5 \pm 0.1(34)$ & $62.9 \pm 8.0(34)$ & $79.9 \pm 4.5(34)$ \\
5 & $1.3 \pm 0.2(20)$ & $79.6 \pm 10.4(20)$ & $89.0 \pm 5.8(20)$ \\
6 & $1.2 \pm 0.2(15)$ & $79.9 \pm 12.5(15)$ & $89.7 \pm 7.0(15)$ \\
$7+$ & $1.5 \pm 0.2(09)$ & $72.9 \pm 15.3(09)$ & $83.2 \pm 8.6(09)$ \\
\hline
\end{tabular}

${ }^{1}$ Traits described in Table 1; ${ }^{2}$ Herd (Site-1-Anwara; Site-2-Chandanaish; Site-3-Nucleus; Site-4Community); ${ }^{* * *}$-significant at $\mathrm{P}<0.001$; NS-non significant $(\mathrm{P}>0.05)$, Figures in parenthesis indicate the number of observations

\section{Herd}

Analysis of variance shows (Table 5) that herd is a highly significant $(\mathrm{P}<0.001)$ source of variation for female fertility traits. Cows in Herds 1 and 2 show significantly higher fertility than cows in Herds 3 and 4 (Table 4) and this might be due to close supervision and better oestrus detection by owners as the herd size is manageable. This finding contradicts the findings of Habib (2011) and variation may be due to sample size. Yifat et al. (2009); Mureda and Zeleke (2007) found no significant (P>0.05) difference in number of services per pregnancy and first service pregnancy rate for crossbred dairy herds in urban and rural areas in Ethiopia. But the present result agrees well with Tadesse et al. (2010) as they detected significant effect $(\mathrm{P}<0.001)$ of herd on services per pregnancy for Holstein-Friesian cows in Ethiopia. DeJarnette et al. (2001) reported no significant effect $(\mathrm{P}>0.05)$ of herd on pregnancy rate. 
Table 5. Analysis of variance for fertility traits

\begin{tabular}{|c|c|c|c|c|c|}
\hline \multirow[t]{2}{*}{ Traits $^{1}$} & \multicolumn{4}{|c|}{$F$ value and significance ${ }^{2}$} & \multirow[t]{2}{*}{$R^{2}$} \\
\hline & Parity & Herd & Season & Bull & \\
\hline NSP & 0.7 & $8.4^{* * *}$ & - & - & 0.11 \\
\hline FSPR & 0.7 & $9.1^{* * *}$ & - & - & 0.12 \\
\hline PR & 0.7 & $9.5^{* * *}$ & - & - & 0.12 \\
\hline NRRFS & 1.3 & 0.1 & 1.7 & 0.5 & 0.05 \\
\hline
\end{tabular}

${ }^{1}$ Traits described in Table 1; $2{ }^{* * *}$-significant at $\mathrm{P}<0.001$; - effect not included in the model; $R^{2}$ coefficient of determination

The herd that used artificial insemination had no significant effect $(\mathrm{P}>0.05)$ on nonreturn rate of RCC bulls (Table 5), which agrees with Habib (2011). But the result does not agree with Miglior et al. (1997) as they found highly significant $(\mathrm{P}<0.001)$ effect of herd on this trait.

Parity

Table 4 shows no specific trend of female fertility traits for different parity and parity has no significant effect on all traits studied (Table 5). The result coincides with Habib (2011). In general agreement with the current result, several studies (Habib et al., 2003; Bhattacharyya et al., 2010; Hammoud et al., 2010) reported non-significant effect of parity/age on these traits. In contrast, Buxadera and Dempfle (1997) reported significant effect of parity on these traits. It is evident from many workers that age is negatively associated with fertility. In the present study parity does not show any significant variation on fertility: this could be due to delayed age at puberty in tropical indigenous cattle.

The parity of cow had no significant $(\mathrm{P}>0.05)$ influence on non-return rate to first service of RCC bull (Table 5), which agrees with the previous study (Habib, 2011). In contrast, Miglior et al. (1997); Rabidas et al. (2010) reported significant influence of age of cow on non-return rate of bull of different breeds in different countries. They stated that heifers (12 to 24 months of age) had higher non-return rate, about $20 \%$ more than older cows.

Season

Season of insemination had no significant influence $(\mathrm{P}>0.05)$ on non-return rate of bulls to first service (Table 5). This result coincides with Habib (2011). Rabidas et al. (2010) found significant effect $(\mathrm{P}<0.05)$ of season of AI on non-return rate to first service in 1650 multiparous crossbred cows sired by five bulls. A decreased rate from July to August was reported by Miglior et al. (1997). Their report does not agree with this study: that may be due to sample size, different breeds, health status of animals and management system. 
Sire

The non-return rate to first service did not differ significantly $(\mathrm{P}>0.05)$ between bulls (Table 5). This is in agreement with Habib (2011). Sarder (2006) studied 71 bull's semen sired on 75550 cows to estimate non-return rate at 60 days and found significant effect $(\mathrm{P}<0.05)$ of individual bull on non-return rate. The contradictory results between authors might be due to small number of bulls.

\section{Heritability estimates}

The variance components and heritability estimates along with corresponding standard errors of different fertility traits of RCC are illustrated in Table 6.

Table 6. Variance components and heritability $( \pm$ SE) estimates of fertility traits

\begin{tabular}{l|c|c|c|c|c}
\hline \multirow{2}{*}{ Traits $^{1}$} & \multicolumn{4}{|c|}{ Variance components } & \multirow{2}{*}{$h^{2} \pm \mathrm{SE}$} \\
\cline { 2 - 5 } & $\begin{array}{c}\text { Additive } \\
\text { genetic }\left(\sigma^{2} \mathrm{~A}\right)\end{array}$ & $\begin{array}{c}\text { Environmental } \\
\left(\sigma_{\mathrm{PE}}^{2}\right)\end{array}$ & Residual $\left(\sigma^{2} \mathrm{E}\right)$ & $\begin{array}{c}\text { Total phenotypic } \\
\left(\sigma^{2} \mathrm{P}\right)\end{array}$ & \\
\hline NSP & 0.039 & 0.071 & 0.459 & 0.569 & $0.07 \pm 0.04$ \\
FSPR & 78.368 & 337.553 & 1997.113 & 2413.034 & $0.03 \pm 0.04$ \\
PR & 36.299 & 106.921 & 612.231 & 755.451 & $0.05 \pm 0.04$ \\
NRRFS & 0 & 20.795 & 2464.970 & 2485.765 & 0 \\
\hline
\end{tabular}

${ }^{1}$ Traits described in Table 1

Table 6 shows that female and male fertility have very low heritability, ranging from 0 to 0.07 . Habib (2011) reported heritability of female fertility traits ranging from $0.04 \pm$ 0.1 to $0.2 \pm 0.1$, and 0 for non-return rate to first service of bulls in the same herds, in line with this study. Some other authors (Lasley, 1978; Warwick and Legates, 1979; Willis, 1998; Demeke et al., 2004; Haas et al., 2007) reported heritability of number of services per pregnancy as very low, ranging from -0.15 to 0.10 , in accordance with this study. For first service pregnancy rate, the result obtained is similar to the $0.01 \pm 0.01$ and $0.03 \pm 0.03$ reported by Bormann et al. (2006); Haas et al. (2007). Dearborn et al. (1973) reported the heritability of pregnancy rate to be 0.09 for beef cattle, which coincides with this result. The heritability estimate of non-return rate to first service of RCC bull is in agreement with the reports (0-0.11) reviewed by Lasley (1978) and Warwick and Legates (1979).

Because of low heritability, selection of animals for improvement of fertility is not likely to be effective.

\section{Repeatability estimates}

The variance analyses results and repeatability along with corresponding standard errors of different repeatable fertility traits are presented in Table 7. 
Table 7 . The variance analyses and repeatability $(\mathrm{r})( \pm \mathrm{SE})$ of fertility traits

\begin{tabular}{l|rr|c}
\hline \multirow{2}{*}{ Traits $^{1}$} & \multicolumn{2}{|c|}{ Variance components } & \multirow{2}{*}{$\pm \mathrm{SE}$} \\
\cline { 2 - 3 } & Variance between animals $\left(\sigma^{2} \mathrm{~B}\right)$ & Variance within animals $\left(\sigma^{2} \mathrm{w}\right)$ & \\
\hline NSP & 0.135 & 0.595 & $0.18 \pm 0.08$ \\
FSPR & 191.432 & 2115.942 & $0.08 \pm 0.07$ \\
PR & 95.681 & 654.538 & $0.13 \pm 0.08$ \\
NRRFS & -155.447 & 2518.131 & $-0.07 \pm 0.02$ \\
\hline
\end{tabular}

1Traits described in Table 1

Table 7 shows that the repeatability estimates of all fertility traits are low, ranging from -0.07 to 0.18 . Habib (2011) in the same herds reported repeatability estimates of $0.14 \pm 0.08,0.10 \pm 0.08$ and $0.13 \pm 0.08$, respectively for number of services per pregnancy, first service pregnancy rate and pregnancy rate, in line with these findings. Lasley (1978); Warwick and Legates (1979); Willis (1998); Demeke et al. (2004) reported repeatability of number of services per pregnancy ranging from 0 to 0.13. Our result is similar. Lasley (1978) reported repeatability estimate of non-return rate to first service from 0.03 to 0.27 .

Considering low level of repeatability of fertility traits, selection for those traits may not be successful. Environment has a great influence on those traits.

\section{Conclusions}

It may be concluded that the fertility of RCC is encouraging as compared with other cattle breeds. However, there is still opportunity to improve overall herd fertility through proper oestrus detection and correct time of insemination by well-trained technicians with good quality semen, proper nutrition supplementation and health management.

\section{Acknowledgments}

The authors thank USDA and Mymensingh ADP, World Vision Bangladesh for funding.

\section{References}

Almquist JO, Flipse RJ, Thaker DL 1995: Diluters of Bovine Semen, IV: Fertility of Bovine Spermatozoa in Heated Homogenized Milk and Skim Milk. Journal of Dairy Science 37 1303-1307.

Azizunnesa BC, Sutradhar M, Hasanuzzaman OF, Miazi M, Aktaruzzaman M, Faruk MO 2010: Study on the Productive and Reproductive Performances of Red Chittagong Cows at Rural Areas in Chittagong. University Journal of Zoology, Rajshahi University 28 27-31. 
Bag MAS, Mannan MA, Khan MSR, Parvez MM, Ullah SM 2010: Morphometric Characterization and Present Status of Red Chittagong Cattle (RCC) in Chittagong District in Bangladesh. International Journal of BioResearch 1 11-14.

Bhattacharyya HK, Fazili MR, Khan I, Bhat FA 2010: Fertility Status of Artificially Inseminated Crossbred Cows of Kashmir Valley. Asian-Australasian Journal of Animal Science 4 56-63.

Bormann JM, Totir LR, Kachman SD, Fernando RL, Wilson and DE 2006: Pregnancy Rate and First-service Conception Rate in Angus Heifers. Journal of Animal Science 84 2022-2025.

Buxadera AM, Dempfle L 1997: Genetic and Environmental Factors Affecting Some Reproductive Traits of Holstein Cows in Cuba. Genetics, Selection and Evolution 29 469-482.

Das S, Bhuiyan AKFH, Begum N, Habib MA, Arefin T 2010: Fertility and Parasitic Load of Red Chittagong Cattle. Bangladesh Veterinarian 27 74-81.

Dearborn DD, Koch RM, Cundiff LV, Gregory KE, Dickerson GE 1973: An Analysis of Reproductive Traits in Beef Cattle. Journal of Animal Science 36 1032-1040.

DeJarnette JM, Salverson RR, Marshall CE 2001: Incidence of Premature Estrus in Lactating Dairy Cows and Conception Rates to Standing Estrus or Fixed-time Inseminations after Synchronization using GnRH and $\mathrm{PGF}_{2 \dot{\alpha}}$. Animal Reproduction Science 67 27-35.

Demeke S, Neser FWC, Schoeman SJ 2004: Estimates of Genetic Parameters for Boran, Friesian and Crosses of Friesian and Jersey with the Boran Cattle in the Tropical Highlands of Ethiopia: Reproduction Traits. Journal of Animal Breeding and Genetics 121 57-65.

Fryer HC, Marion GB, Farmer EL 1958: Non-return Rate of Artificially Inseminated Dairy Cows as Affected by Age of Semen, Breed of Bull, and Season. Journal of Dairy Science 41 987-993.

Goshu G, Belihu K, Berihum A 2007: Effect of Parity, Season and Year on Reproductive Performance and Herd Life of Friesian Cows at Stella Private Dairy Farm, Ethiopia. Livestock Research for Rural Development 19 Article. 98 (http://www.lrrd.org/ lrrd19/7/gosh19098.htm).

Groeneveld E 1998: VCE4.2.5 User's Guide and Reference Manual Version 1.1. Institute of Animal Husbandry and Animal Behaviour, Mariensee, Federal Agricultural Research Center, Germany.

Haas DY, Janss LLG, Kadarmideen HN 2007: Genetic and Phenotypic Parameters for Conformation and Yield Traits in three Swiss Dairy Cattle Breeds. Journal of Animal Breeding and Genetics 124 12-19.

Habib MA 2011: Analysis of Red Chittagong Cattle Genotype in Nucleus Breeding Herd. PhD Dissertation, Department of Animal Breeding and Genetics, Faculty of Animal Husbandry, Bangladesh Agricultural University, Mymensingh, Bangladesh, pp. 158. 
Habib MA, Bhuiyan AKFH, Bhuiyan MSA, Khan AA 2003: Performance of Red Chittagong Cattle in Bangladesh Agricultural University Dairy Farm. Bangladesh Journal of Animal Science 32 101-108.

Hammoud HM, El-Zarkouny SZ, Oudah EZM 2010: Effect of Sire, Age at First Calving, Season and Year of Calving and Parity on Reproductive Performance of Friesian Cows under Semiarid Conditions in Egypt. Archieve Zootechnique 13 60-82.

Hossain MM, Bhuiyan AKFH, Faruque MO, Dev GK 2006: Characterization and Distribution Pattern of Red Chittagong Cattle of Bangladesh. Progressive Agriculture 17 103-110.

Lasley JF 1978: Genetics of Livestock Improvement. $3^{\text {rd }}$ edition, Prentice-Hall, Inc., Eaglewood Cliffs, New Jersey, USA. pp. 1-492.

Lush JL 1945: Animal Breeding Plans. $3^{\text {rd }}$ ed. Iowa State College Press, Ames, USA.

McDowell RE 1985: Crossbreeding in Tropical Areas with Emphasis on Milk, Health and Fitness. Journal of Dairy Science 68 2418-2435.

Miglior F, Pizzi F, Guaita N 1997: Effect of Environmental Factors on Non-return rate in Italian Holstein-Friesians. Interbull Mtg. Grub. Uppsala, Sweden, International bulletin No. 18 , pp. 106-108.

Mukasa-Mugerwa E 1989: A Review of Reproductive Performance of Female Bos indicus (Zebu) Cattle. ILCA, Monograph No. 6. International Livestock Center for Africa, Addis Ababa, Ethiopia (http://www.ilri.org/InfoServ/Webpub/Fulldocs/X5442e/ X5442e00.htm)

Mureda E, Zeleke ZM 2007: Reproductive Performance of Crossbred Dairy Cows in Eastern Lowlands of Ethiopia. Livestock Research for Rural Development 19 (http://www.lrrd.org/lrrd19/11/mure19161.htm)

Rabidas SK, Alam MGS, Bari FY, Talukdar AK 2010: Semen Qualities and Non return Rate of Bulls. 26 ${ }^{\text {th }}$ World Buiatrics Congress, November $14-18$, Santiago, Chile.

Radostits OM 2001: Herd Health: Food Animal Production Medicine. Third Edition. Philadelphia. USA, pp. 255-289.

Rodriguez HT, Hernandez C 1992: Effect of Time of Insemination and Rectal Temperature on Fertility in Cows. Animal Breeding Abstract 60288.

Sarder MJU 2006: Evaluation of Semen Fertility of Bulls by Non-Return Rate at 60 Days of Cows under Artificial Insemination in Bangladesh. Pakistan Journal of Biological Science $92707-2714$.

Schaeffer LR 1993: Evaluation of Bulls for Non-return Rates within Artificial Insemination Organizations. Journal of Dairy Science 76 837-842.

Shiferaw Y, Tenhagn BA, Bekana M, Kassa T 2003: Reproductive Performance of Crossbred Dairy Cows in Different Production Systems in the Central Highlands of Ethiopia. Tropical Animal Health and Production 25 551-561. 
Swiger LA, Harvey WR, Everson DO, Gregory KE 1964: The Variance of Intraclass Correlation Involving Groups with one Observation. Biometrics 20 818-826.

Tadesse B, Zelalem Y 2003: Feeding Noug 'Guizotia abyssinica' Cake as Protein Source to Lactating Borana' Jersey Crossbred Cows: Performances in Milk Yield, Reproduction and Feed Efficiency. Farm Animal Biodiversity: Status and Prospects. Proceeding, 11 $11^{\text {th }}$ Annual Conference of the Ethiopian Society of Animal Production (ESAP), 28-30 August 2000, Addis Ababa, Ethiopia.

Tadesse M, Thiengtham J, Pinyopummin A, Prasanpanich S 2010: Productive and Reproductive Performance of Holstein Friesian Dairy Cows in Ethiopia. Livestock Research for Rural Development 22 (http:/ / www.lrrd.org/lrrd22/2/tade22034.htm).

Warwick EJ, Legates JE 1979: Breeding and Improvement of Farm Animals. $7^{\text {th }}$ edn. Tata McGraw-Hill Publishing Company Ltd. New Delhi, India, pp. 1-624.

Willis MB 1998: Dalton's Introduction to Practical Animal Breeding. $4^{\text {th }}$ ed. Blackwell Sc. London, pp. 166

Yifat D, Kelay B, Bekana M, Lobago F, Gustafsson H, Kindahl H 2009: Study on Reproductive Performance of Crossbred Dairy Cattle under Smallholder Conditions in and around Zeway, Ethiopia. Livestock Research for Rural Development 21http:/ /www.lrrd.org/ lrrd 21/6/yifa21088.htm.

Zakari AY, Molokwu ECL, Osori DIK 1981: Effect of Rectal and Ambient Temperature and Humidity on Conception Rate. Theriogenology 17 331-336. 